\title{
EXAMINING PROACTIVE CAREER MANAGEMENT BEHAVIOUR, READINESS AND GRADUATENESS AMONG FIRST DEGREE STUDENTS IN SELECTED PUBLIC UNIVERSITIES
}

\author{
D Syed Jamal Abdul \\ Nasir $^{1}$ \\ (iD) Nur Ain Syazmeen \\ Ahmad Zaki ${ }^{2+}$
}

\author{
'Arshad Ayub Graduate Business School (AAGBS), Universiti Teknologi \\ MARA Shah Alam, Malaysia. \\ Email:syedjamal145@uitm.edu.myTel:+603-55444697 \\ ${ }^{2}$ Faculty of Business Management, Universiti Teknologi MARA Shah Alam, \\ Malaysia. \\ Email:ainsyazmeen@gmail.com Tel:+6012-6504978
}

\section{ABSTRACT}

(D) Check for updates

\section{Article History}

Received: 4. February 2021 Revised: 8 March 2021

Accepted: 6 April 2021

Published: 28 April 2021

\section{Keywords}

Graduateness

Proactive career management

behavior

Readiness

Social cognitive career theory

Graduates higher learning

education.
In this competitive world, graduates have to equip themselves with proper skills and knowledge to acquire jobs. Getting a degree from higher education institutions has become necessary for any individual to get a decent placement in the workforce. This study examines proactive career management behaviour, readiness and graduateness by employing the Social Cognitive Career Theory (SCCT) as the research framework. Total of 114 respondents among first degree students in selected public universities in Klang Valley completed a survey questionnaire measuring their response to related variables. Partial Least Square (PLS) was used as the technique for data analysis. Results indicate proactive career management behaviour and readiness influence the graduateness of first degree students. The results from this research hope to obtain greater insights into the applicability of SCCT in future research on this unique topic and help the government to find ways to enhance graduateness of students from any higher learning educations in Malaysia. The study contributes in the existing literature. The study in one of very few studies which have investigated

Contribution/ Originality: This study contributes to the existing literature in which the social cognitive career theory supported findings of proactive career management behaviour and readiness where the social cognitive career theory has exhibited greater predictive power.

\section{INTRODUCTION}

The issue of unemployment among fresh graduates in the country is quite alarming. In Malaysia, similar concerns were highlighted about the number of fresh graduates who are still unemployed after six months of graduation. According to statistics from (Department of Statistics, 2020) the unemployment in Malaysia rose to 1.4 per cent as compared to the earlier year which is 3.3 per cent on 2019. The number of unemployed persons also increased by 221,400 persons from 520, 200 persons from previous year. The ratio of youth unemployment to the national average has been ascending over the past decade. In July 2020, more than 80 percent of the unemployed persons were actively unemployed, where 49.2 per cent were unemployed for less than three months. In comparing against age group, the unemployment rate of youth is always higher than the overall adults where youth aged 15 to 24 years with 13.7 per cent meanwhile adults with 9.7 per cent unemployment rate.

Given the significance of career and work in an individual's life, it is vital to comprehend the possible characteristics and behaviour that can affect the individual's career route and advancement. Moreover, career 
opportunities for young adults to the job market seem riskier, more adventurous and less defined than a generation in the past (Dolphin, Gottfried, Raikes, Silim, \& Thompson, 2014). The challenges that all country facing especially in Malaysia such as globalization, climate change, technological advancement and demographic change require an alternate solution from the education system. Youth themselves need to be innovative and should be able to recognize any opportunity to compete with others (Ngah, Samiidy, \& Hali, 2020).

According to Tansley, Jome, Haase, and Martens (2007) undergraduates may not be engaging with their employability early enough to achieve positive career outcomes. Shifts in economies throughout the world imply that employers are highly searching for a set of generic skills and technical skills to meet the demand of their customers and clients. These sets of skills could be viewed as graduateness since it is vital for students and graduates to have competencies and qualities of graduateness upon their graduation. Graduateness is imperative in light of the fact the employment market is seriously aggressive and managers in the private and public sectors are searching for individuals who are risk takers, daring, flexible, initiated and can embrace multiple tasks in various conditions (Coetzee, 2012).

This study aims to examine on how proactive career management behaviour and readiness affect graduateness of students in the framework of Social Cognitive Career Theory (SCCT) model. The research model and hypothesized relationship were empirically tested using the Partial Least Squares (PLS) approach.

\subsection{Underpinning Theory}

The theory employed to develop the framework originated from the Social Cognitive Career Theory (SCCT). This theory offers a useful framework for understanding proactive career management behaviour, readiness and graduateness of students. Based on Bandura (1986) social cognitive theory, SCCT focuses on the relationship among the individual, the environment and behavioural influences during career development (Lent, Brown, \& Hackett, 1994). Therefore, this theory is used in this study as the framework for examining proactive career management behaviour, readiness and graduateness among first degree students.

According to SCCT, the interaction among people, the environment and behavioural effects influence how individuals develop their work readiness, revise their career and academic plans and perform in their pursuit of a career and academics. Three main tenet of this theory is that variables from the environment are interpreted by the individual, which leads to differences in self-efficacy, outcome expectations and career goals within the individual (Lent et al., 1994). According to the theory, people are likely to persist in goal-directed behaviour for which they have high levels of self-efficacy, provided the valued outcomes are expected to result from the behaviour. SCCT views this process as important to the development of interests to career goals. Therefore, proactive career management behaviour is an important factor influencing graduateness of students. Figure 1 below shows the main tenets of SCCT.

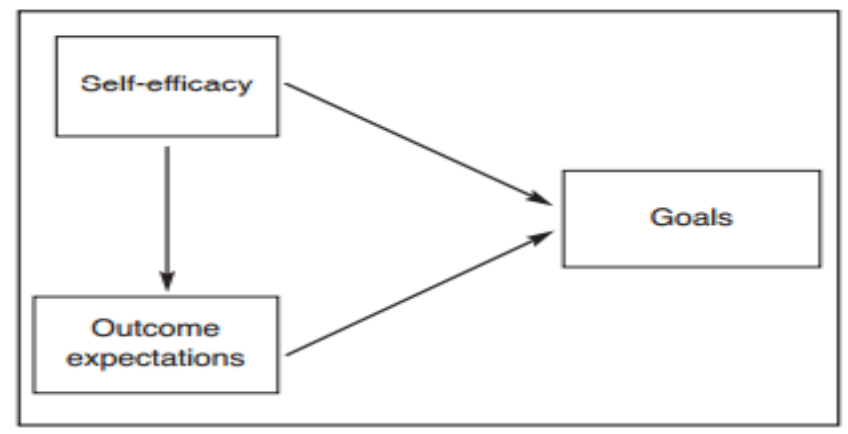

Figure-1. Main tenets of SCCT (Lent et al., 1994). Social cognitive career theory. Career choice and development, 4, 255-311. Source: Lent et al. (1994). 


\section{LITERATURE REVIEW}

\subsection{Proactive Career Management Behaviour (PCMB)}

Proactive career management behaviour incorporates the deliberate activities undertaken by individuals with a specific end goal to understand their career goals (Orpen, 1994). Proactive career behaviour occurs when people choose to initiate, intervene in, or perceive of a career situation in such a way that the agent acts in valued directions rather than responds passively to imposed change (Fryer \& Payne, 1984). De Vos, Dewettinck, and Buyens (2009) added that career management behaviour enable individuals to increase self and environmental awareness and eventually invent strategies allowing adaptability to labour market conditions. In Malaysia, career management outlook is in the process of transformation and development to one that integrate elements of the US and European career management approaches, in addition to the influence of Asian approaches that focus on relationships and collectivist oriented activities (Rasdi, Garavan, \& Ismail, 2011).

Despite the fact that the results of several studies show a positive relationship between proactive career management and end results such as organizational career management support (Strauss, Griffin, \& Parker, 2012) and career progression (Seibert, Kraimer, \& Crant, 2001) less exploration has been made in researching the nature and process of proactive career management behaviour (De Vos et al., 2009). Nonetheless, proactive personality, career self-efficacy, social support, job searching and networking are all positively correlated with each other (McArdle, Waters, Briscoe, \& Hall, 2007).

\subsection{Readiness}

Readiness is the degree to which graduates are seen to have the attitudes and attributes that make them ready and prepared for success in the workplace (Cabellero \& Walker, 2010). Readiness can be referred as to extent to which graduates are perceived to have the abilities and attributes that make them prepared or ready for success in the work environment (Cabellero \& Walker, 2010). Work readiness can also be referred as the degree to which graduates are work prepared is viewed as indicative of potential in terms of job performance, success and potential for promotion and career advancement (Caballero, Walker, \& Fuller-Tyszkiewicz, 2011). Through readiness, students have the ability to explore career preferences while obtaining graduateness and other skills required of any occupation.

According to Pyöriä, Ojala, Saari, and Järvinen (2017) the younger adults are more prepared to change to a different occupational field as compared to older generations. However, according to Woo and Park (2017) students who were motivated mainly by job stability was lower compared to those individuals who were motivated by job value, aptitude or interests. This is consistent to the previous study in which shows that graduates possess in several key skills; oral and written communication, critical thinking and creativity are more than twice as likely as employers to believe that they are well-prepared for work (Howieson et al., 2014).

\subsection{Graduateness}

Chetty (2012) defined graduateness as the skills, knowledge and understanding graduate possess. Walsh and Kotzee (2010) refers graduateness as the quality that graduates have that sets them up for the graduate-level work or notwithstanding for work all things considered. On the other hand, Kizito (2010) define graduateness as the degree to which the set of graduate characteristics have been accomplished. Tran (2016) added that there has been an increasing pressure on higher education to produce students with prepared skills and knowledge as expected by the current labour market. However, according to Heang, Ching, Mee, and Huei (2019) graduates are not wellprepared and ready for the working world despite possessing an undergraduate degree due to the curriculums provided by the higher education institutions itself overly emphasize on the theoretical aspects rather the skills that students should possess in the early year of study. 
Therefore, in order to be employable, graduates need to be capable of prioritising and goal setting, be proactive in the management of change, possess necessary skills for self-advocacy and networking to cope with changing circumstances, be active in maintenance of continuous learning and capable of working within changing teams (Glover, Law, \& Youngman, 2002). According to Coetzee (2017) graduates' career outcomes could largely be attributed with self-efficacy such as graduates' social capital and goal-directedness. Supported by Chughtai (2019) proactive career planning, skills development and networking behaviour were positively associated with perceived employability.

\subsection{Gap in Previous Studies}

Proactive career management behaviour plays a significant role among higher institutions graduates. It is important for undergraduates to have this kind of behaviour to plan and prepare for the shift from universities into their careers, which is a critical step in career development theories and for some career counsellor experts (Super, 1990). On a general level, there is a lack of validated measures that directly measures proactive career management behaviour which hinders the empirical assessment of career development theories that results existing research in this field difficult to differentiate. Additionally, current scales of career management are mostly only appropriate for workers and are less relevant for the graduates (Hirschi, Freund, \& Herrmann, 2014).

This study depicts the development and validation that specifically measures the general level of engagement in proactive career management behaviour among undergraduates from public universities to address the need for a solid general measure of proactive career management behaviour. There is a gap in the Malaysian community regarding the literature of work readiness among Malaysian graduates. At present, there is scarce data on employers' and employees' comprehension of what constitutes readiness and this proves that there is a growing need to evaluate deliberately readiness as a constructs. In addition, Verma et al. (2018) recognized readiness as a top challenge of employers in the Malaysia, Indonesia \& Australia. Hence, this study is an attempt to fill this gap and provide insights of graduateness in Malaysian context.

\section{METHODOLOGY}

After the background of study been identified, researcher establish the flow of the research in this section. It also explains the methodology and variables analyzed in this study.

\subsection{Research Site and Subjects}

The study took place in selected public universities in Klang Valley which includes Universiti Islam Antarabangsa Malaysia (UIAM), Universiti Teknologi MARA (UiTM), Universiti Kebangsaan Malaysia (UKM), Universiti Malaya (UM) and Universiti Putra Malaysia (UPM). Students' participation was voluntary. Initially, 120 questionnaires were distributed to 120 students, but six of them were discarded from further analysis as they contained many unanswered questions. From 114 respondents, 67 (58.8\%) were female and 47 (41.2\%) were male.

\subsection{Profile of Respondents}

The majority of respondents (74.6\%) were Malays, followed by other races (14.9\%), Indian (6.1\%) and Chinese (4.4\%). About 97.4 percent were single. Further, 71.1 percent were age ranged from twenty-one years old to twenty-nine years old, 27.2 percent were below twenty years old and only 1.8 percent were ranged between thirty to thirty-nine years old. There were 63.2 percent were from social sciences cluster and 36.8 percent from science and technology cluster. For their universities, 19.3 percent of the respondents were from Islam Antarabangsa Malaysia (UIAM) and 20.2 percent were from Universiti Teknologi MARA (UiTM), Universiti Kebangsaan Malaysia (UKM), Universiti Malaya (UM) and Universiti Putra Malaysia (UPM) respectively. 


\subsection{Procedure}

The questionnaire was administered to the respondents in each universities during ongoing semester. Almost all of the potential respondents who were approached by researcher agreed to spend little time to take part in the study. Researcher clearly stated to the respondents from the beginning that all the information taken from the questionnaire would remain confidential. Instructions on how to answer the questionnaire were given to them and they were asked to return the completed questionnaire after they finish answering it.

\subsection{Measures and Data Collection}

Previous validated studies were taken and the items from those studies were used in the survey questions. A six point Likert scales ( 1 - strongly disagree to 6 - strongly agree) were utilized to measure all constructs which was adopted and adapted from previous studies. The questionnaire that is used in the study consists of four different sections intended to measure graduateness. The first section consists of demographic characteristics questions; gender, age, ethnicity, universities, cluster and marriage status. The second part was meant to measure the variables proactive career management behaviours among first degree students. The third part was intended to measure the influence of readiness towards graduateness among undergraduates. The last part of questionnaire was meant to measure the graduateness of students. The statements for the proactive career management behaviour (PCMB) attributes, the statements were adapted from Gould (1979); Stumpf, Colarelli, and Hartman (1983); Strauss et al. (2012); Wolff and Moser (2009) while the readiness attributes, statements were adapted from Caballero. et al. (2011). Finally, the statements of graduateness were adapted wholly from Coetzee (2012) past research on measuring students' graduateness.

\section{DATA ANALYSIS}

To analyze the data collected, the PLS were used. The reasons for using this technique are like covariance based structural equation modelling, PLS is also primarily due to the method's improved ability to assess the reliability and validity of multi-item construct measures as well as test structural model relationships (Hair Jr, Matthews, Matthews, \& Sarstedt, 2017). Also PLS is far less restrictive in its distributional assumption and PLS applies to situations where knowledge about the distribution of the latent variable is limited and requires the estimates to be more closely tied to the data compared to covariance structure analysis (Fornell \& Cha, 1994). The Smart PLS M2 Version 2.0 (Ringle, Wende, \& Will, 2005) and two-step analysis approach as suggested by Anderson and Gerbing (1988) was adopted to analyze the data. Also following the suggestions of Chin (1998); GilGarcia (2008) the bootstrapping method of 200 resamples was done to determine the significance levels for loadings, weights and path coefficients.

\subsection{Goodness of Measures}

The 2 main criteria used for testing goodness of measures are validity and reliability. Reliability is a test of how consistently a measuring instrument measures whatever concept it is measuring whereas validity is a test of how well an instrument that is developed measures the particular concept it is intended to measure (Sekaran \& Bougie, 2010).

\subsubsection{Construct Validity}

Construct validity testifies to how well the results obtained from the use of the measure fit the theories around which the test is designed (Sekaran \& Bougie, 2010). Table 1 below shows the loadings and cross loading. The table shows that all items measuring the same construct loaded highly on that particular construct and loaded lower on other constructs indicating convergent and discriminant validity. 
Table-1. Loadings and cross loadings

\begin{tabular}{|c|c|c|c|c|}
\hline Model Construct & $\begin{array}{c}\text { Measurement } \\
\text { Item }\end{array}$ & Graduateness & $\begin{array}{c}\text { Proactive Career } \\
\text { Management Behaviour }\end{array}$ & Readiness \\
\hline \multirow{4}{*}{ Graduateness } & GRAD1 & 0.713 & 0.493 & 0.358 \\
\hline & GRAD3 & 0.728 & 0.428 & 0.376 \\
\hline & GRAD4 & 0.75 & 0.528 & 0.414 \\
\hline & GRAD6 & 0.699 & 0.419 & 0.543 \\
\hline \multirow{4}{*}{$\begin{array}{l}\text { Proactive } \\
\text { Management } \\
\text { Behaviour }\end{array}$} & PCMB1 & 0.536 & 0.856 & 0.414 \\
\hline & $\mathrm{PCMB} 2$ & 0.533 & 0.891 & 0.508 \\
\hline & PCMB3 & 0.603 & 0.878 & 0.577 \\
\hline & $\mathrm{PCMB} 4$ & 0.624 & 0.815 & 0.406 \\
\hline \multirow[t]{3}{*}{ Readiness } & Rea3 & 0.556 & 0.525 & 0.864 \\
\hline & Rea4 & 0.555 & 0.477 & 0.897 \\
\hline & Rea5 & 0.543 & 0.507 & 0.815 \\
\hline
\end{tabular}

Source: PLS-SEM (Smart PLS 3) Output.

\subsubsection{Convergent Validity}

Convergent validity which is the degree to which multiple items to measure the same concept are in agreement are tested. As suggested by Hair, Black, Babin, and Anderson (2010) factor loadings, composite reliability and average variance extracted are used to assess convergence validity. The loadings for all items exceeded the recommended value of 0.5 (Hair et al., 2010). Table 2 shows that the loadings ranging from 0.687 to 0.891 .

Composite reliability values in Table 2, which depict the degree to which the construct indicators indicate the latent, construct range from 0.868 to 0.935 which exceeded the recommended value of 0.7 (Hair et al., 2010). The average variance extracted ( $\mathrm{AVE}$ ) measures the variance captured by the indicators relative to measurement error, and it should be greater than 0.5 to justify using a construct (Hair et al., 2010). The average variance extracted from the study, were in the range of 0.522 and 0.743 as shown in Table 2.

Table-2. Results of CFA for measurement model.

\begin{tabular}{|c|c|c|c|c|}
\hline & Loadings & AVE & $\overline{C R}$ & Cronbach \\
\hline GRAD1 & 0.713 & 0.522 & 0.868 & 0.817 \\
\hline GRAD 2 & 0.687 & & & \\
\hline GRAD3 & 0.728 & & & \\
\hline GRAD4 & 0.75 & & & \\
\hline GRAD5 & 0.756 & & & \\
\hline GRAD6 & 0.699 & & & \\
\hline PCMB 1 & 0.856 & 0.688 & 0.916 & 0.885 \\
\hline $\mathrm{PCMB} 2$ & 0.891 & & & \\
\hline РCMB3 & 0.878 & & & \\
\hline $\mathrm{PCMB}_{4}$ & 0.815 & & & \\
\hline PCMB5 & 0.69 & & & \\
\hline Rea 1 & 0.864 & 0.743 & 0.935 & 0.914 \\
\hline Rea2 & 0.868 & & & \\
\hline Rea3 & 0.864 & & & \\
\hline Rea4 & 0.897 & & & \\
\hline Rea5 & 0.815 & & & \\
\hline
\end{tabular}

Note: * Composite Reliability $(\mathrm{CR})=$ (square of the summation of the factor loadings)/(square of the summation of the factor loadings) $+($ square of the summation of the error variances)

*Average Variance Extracted $(\mathrm{AVE})=$ (summation of the square of the factor loadings) $/($ summation of the square of the factor loadings $)+($ summation of the error variances).

The Fornell and Larcker (1981) criterion was used to test discriminant validity (see Table 3). 
Table-3. Discriminant validity of construct.

\begin{tabular}{|c|c|c|c|}
\hline Construct & 1 & 2 & 3 \\
\hline 1. Graduateness & 0.723 & & \\
\hline 2. Proactive Career Management Behaviour & 0.662 & 0.829 & \\
\hline 3. Readiness & 0.594 & 0.549 & 0.862 \\
\hline
\end{tabular}

\subsection{Hypotheses Testing}

Next process is proceeded with the path analysis to test the 3 hypotheses generated. Results of structural model are presented in Table 4 and Figure 2.

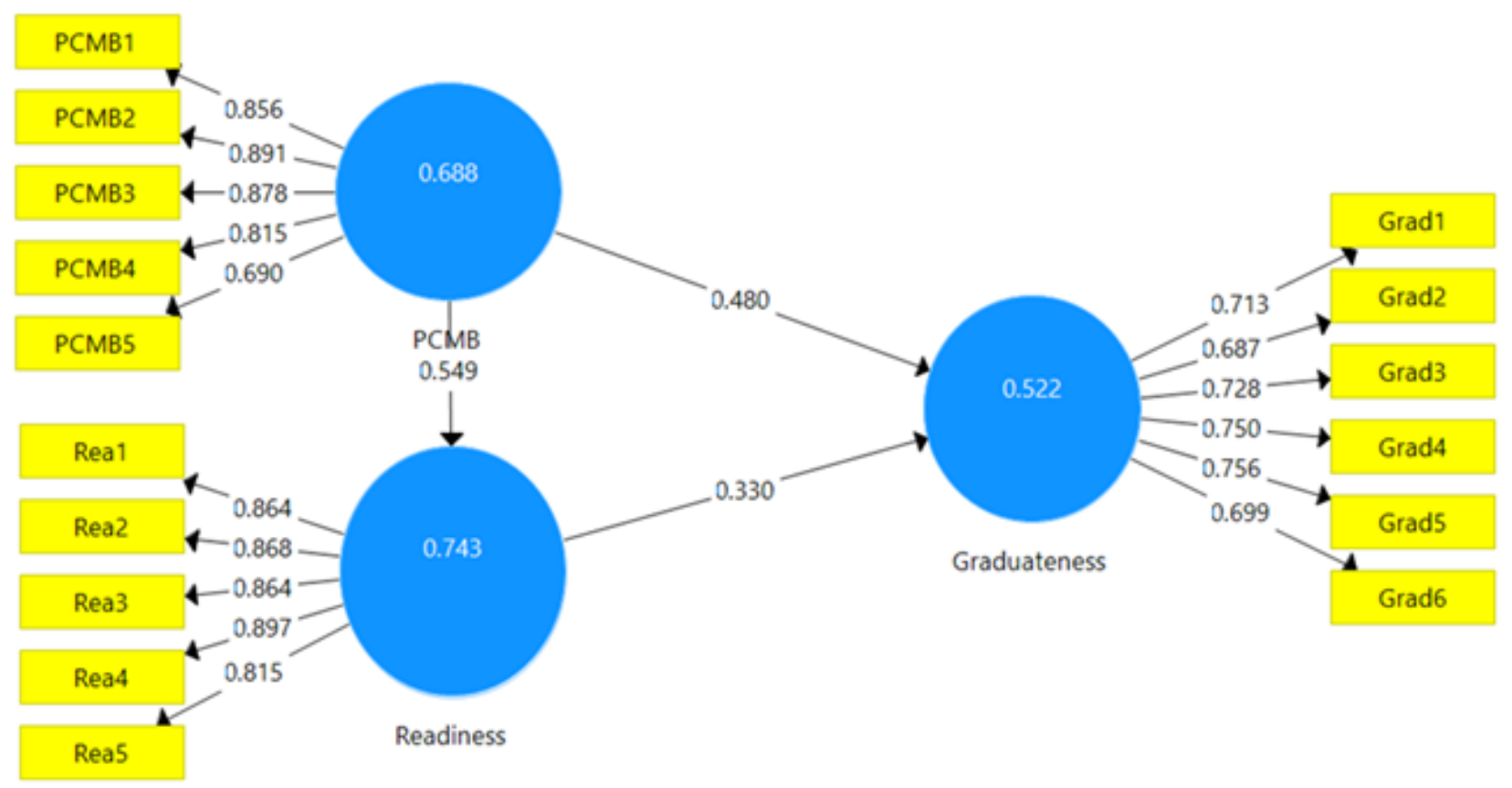

Source: PLS-SEM (Smart PLS 3) Output

Figure-2. Structural Model with loadings.

Table-4. Results of structural model.

\begin{tabular}{|c|c|c|c|c|}
\hline Hypothesis & Relationship & Coefficient & t-value & Decision \\
\hline $\mathrm{H} 1$ & $\begin{array}{l}\text { Proactive Career Management Behaviour - } \\
>\text { Graduateness }\end{array}$ & 0.480 & $5.862^{* *}$ & Supported \\
\hline $\mathrm{H} 2$ & $\begin{array}{l}\text { Proactive Career Management Behaviour - } \\
>\text { Readiness }\end{array}$ & 0.549 & $8.972^{* *}$ & Supported \\
\hline H3 & Readiness -> Graduateness & 0.330 & $3.914^{* * *}$ & Supported \\
\hline
\end{tabular}

\section{CONCLUSIONS}

To determine the factors that influence graduateness among first degree students, proactive career management behaviour and readiness were examined. The findings show that these variables have positive effects on the graduateness on first degree students in Klang Valley. A number of key findings have been presented as a result of the research. First, a quantitative analysis of graduateness on PCMB and readiness among degree student in selected universities revealed a number of interesting trends. As might be expected, undergraduates who have planned ahead for their career future are more prepared to enter the workforce. Component of career-related proactivity represents a critical phase of the proactive career management behaviour process because it enables individuals to connect what they anticipate psychologically with concrete steps and plans (Grant \& Ashford, 2008). This involve thinking about the type of job or work environment that would allow students to enhance their graduateness that match to their prospective job and work environment. Second, the results for the data analysis 
discovered that proactive career management behaviour and readiness has been found to influence graduateness of undergraduates. This results supported the statement of which individual with proactive career management behaviour more actively strive to attain their desired career goals which in turn should make them feel more successful in their career (Arthur, Khapova, \& Wilderom, 2005; Ng, Eby, Sorensen, \& Feldman, 2005).

The limitations of the research derive, first of all, from the fact that the sample of respondents was small in order to consider the results of the research applicable to overall population of degree students in Malaysia. Therefore, the next aim is to extend this research to a bigger number of students and getting the sample for private higher learning institutions as well so a meaningful comparison can be made with richer insight from both sectors. Despite the limitations, our study conveys significant implications for graduateness, particularly in understanding the types of variables that may reinforce proactive career management behaviour and readiness among graduates.

Funding: This research project was funded by Research Management Centre (Universiti Teknologi MARA) under Kementerian Pengajian Tinggi Malaysia through its Geran Insentif Penyeliaan (GIP).

Competing Interests: The authors declare that they have no competing interests.

Acknowledgement: The researchers thank the Arshad Ayub Business Graduate School and Faculty of Business \& Management for providing facilities. Project code: 600-IRMI 5/3/GIP (057/2019).

\section{REFERENCES}

Anderson, J. C., \& Gerbing, D. W. (1988). Structural equation modeling in practice: A review and recommended two-step approach. Psychological Bulletin, 103(3), 411-423. Available at: https://doi.org/10.1037/0033-2909.103.3.411.

Arthur, M. B., Khapova, S. N., \& Wilderom, C. P. (2005). Career success in a boundaryless career world. Journal of Organizational Behavior: The International Journal of Industrial, Occupational and Organizational Psychology and Behavior, 26(2), 177 - 202. Available at: https://doi.org/10.1002/job.290.

Bandura, A. (1986). The explanatory and predictive scope of self-efficacy theory. Journal of Social and Clinical Psychology, 4(3), 359-373. Available at: https://doi.org/10.1521/jscp.1986.4.3.359.

Caballero, C. L., Walker, A., \& Fuller-Tyszkiewicz, M. (2011). The Work Readiness Scale (WRS): Developing a measure to assess work readiness in college graduates. Journal of Teaching and Learning for Graduate Employability, 2(2), 41-54. Available at: https://doi.org/10.21153/jtlge2011vol2no1art552.

Cabellero, C. L., \& Walker, A. (2010). Work readiness in graduate recruitment and selection: A review of current assessment methods. Journal of Teaching and Learning for Graduate Employability, 1(1), 13-25. Available at: https://doi.org/10.21153/jtlge2010vol 1no1art546.

Chetty, Y. (2012). Graduateness and employability within the higher education environment: A focused review of the literature.

In M. Coetzee, J. Botha, N. Eccles, N. Holtzhausen, \& H. Nienaber (Eds.), Developing student graduateness and employability: Issues, provocations, theory and practical guidelines (pp. 119-152). Randburg: Knowres.

Chin, W. W. (1998). The partial least squares approach to structural equation modeling. Modern Methods for Business Research, 295(2), 295-336.

Chughtai, A. (2019). Servant leadership and perceived employability: Proactive career behaviours as mediators. Leadership छ Organization Development Journal, 4O(2), 213-229. Available at: https://doi.org/10.1108/lodj-07-2018-0281.

Coetzee, M. (2012). A framework for developing student graduateness and employability in the economic and management sciences at the University of South Africa. In M. Coetzee, J. Botha, N. Eccles, N. Holtzhausen, \& H. Nienaber (Eds.), Developing student graduateness and employability: Issues, provocations, theory and practical guidelines (pp. $119-$ 152). Randburg: Knowres.

Coetzee, M. (2017). Graduates' psycho-social career preoccupations and employability capacities in the work context. In Graduate employability in context (pp. 295-315). London: Palgrave Macmillan. 
De Vos, A., Dewettinck, K., \& Buyens, D. (2009). The professional career on the right track: A study on the interaction between career self-management and organizational career management in explaining employee outcomes. European Journal of Work and Organizational Psychology, 18(1), 55-80. Available at: https://doi.org/10.1080/13594320801966257.

Department of Statistics. (2020). Labour force survey report. putrajaya. Malaysia: Department of Statistics.

Dolphin, T., Gottfried, G., Raikes, L., Silim, A., \& Thompson, S. (2014). European jobs and skills. A comprehensive review. London: Institute for Public Policy Research.

Fornell, C., \& Larcker, D. F. (1981). Evaluating structural equation models with unobservable variables and measurement error. Journal of Marketing Research, 18(1), 39-50.

Fornell, C., \& Cha, J. (1994). Partial least squares", in Bagozzi, R.P. (Ed.), Advanced methods of marketing research. Cambridge: Blackwell.

Fryer, D., \& Payne, R. (1984). Proactive behaviour in unemployment: Findings and implications. Leisure Studies, 3(3), 273-295. Available at: https://doi.org/10.1080/02614368400390231.

Gil-Garcia, J. R. (2008). Using partial least squares in digital government research. In Garson, G. D., \& Khosrow-Pour, D. B. A. M., (Eds), Handbook of research on public information technology (pp. 239-253): IGI Global.

Glover, D., Law, S., \& Youngman, A. (2002). Graduateness and Employability: Student perceptions of the personal outcomes of university education. Research in Post-Compulsory Education, 7(3), 293-306. Available at: https://doi.org/10.1080/13596740200200132.

Gould, S. (1979). Characteristics of career planners in upwardly mobile occupations. Academy of Management Journal, 22(3), 539550. Available at: https://doi.org/10.5465/255743.

Grant, A. M., \& Ashford, S. J. (2008). The dynamics of proactivity at work. Research in Organizational Behavior, 28,3 - 34. Available at: https://doi.org/10.1016/j.riob.2008.04.002.

Hair, J. F., Black, W. C., Babin, B. J., \& Anderson, R. E. (2010). Multivariate data analysis: A global perspective (7th ed.). Englewood Cliffs: Prentice Hall.

Hair Jr, J. F., Matthews, L. M., Matthews, R. L., \& Sarstedt, M. (2017). PLS-SEM or CB-SEM: Updated guidelines on which method to use. International Journal of Multivariate Data Analysis, 1(2), 107-123. Available at: https://doi.org/10.1504/ijmda.2017.10008574.

Heang, L. T., Ching, L. C., Mee, L. Y., \& Huei, C. T. (2019). University education and employment challenges: An evaluation of fresh accounting graduates in Malaysia. International Journal of Academic Research in Business and Social Sciences, 9(9), 1061-1076. Available at: https://doi.org/10.6007/ijarbss/v9-i9/6396.

Hirschi, A., Freund, P. A., \& Herrmann, A. (2014). The career engagement scale: Development and validation of a measure of proactive career behaviors. Journal of Career Assessment, 22(4), 575-594. Available at: https://doi.org/10.1177/1069072713514813.

Howieson, B., Hancock, P., Segal, N., Kavanagh, M., Tempone, I., \& Kent, J. (2014). Who should teach what? Australian perceptions of the roles of universities and practice in the education of professional accountants. Journal of Accounting Education, 32(3), 259-275. Available at: https://doi.org/10.1016/j.jaccedu.2014.05.001.

Kizito, N. (2010). Negotiating meaning around of graduateness in South African higher education: Practices and dilemmas in designing 21st century curricula. Paper presented at the Presentation at the 4th Annual Conference On The Scholarship Of Teaching And Learning, 11 - 12 May at Stellenbosch University.

Lent, R. W., Brown, S. D., \& Hackett, G. (1994). Toward a unifying social cognitive theory of career and academic interest, choice, and performance. Journal of Vocational Behavior, 45(1), 79-122. Available at: https://doi.org/10.1006/jvbe.1994.1027.

McArdle, S., Waters, L., Briscoe, J. P., \& Hall, D. T. T. (2007). Employability during unemployment: Adaptability, career identity and human and social capital. Journal of Vocational Behavior, 71(2), 247-264. Available at: https://doi.org/10.1016/j.jvb.2007.06.003. 
Ng, T. W., Eby, L. T., Sorensen, K. L., \& Feldman, D. C. (2005). Predictors of objective and subjective career success: A metaanalysis. Personnel Psychology, 58(2), 367 - 408. Available at: https://doi.org/10.1111/j.1744-6570.2005.00515.x.

Ngah, R., Samiidy, R., \& Hali, N. (2020). Implications of generic skills on innovative behavior towards opportunity recognition in youth. Research in World Economy, 11(1), 123-129. Available at: https://doi.org/10.5430/rwe.v1 1n 1p123.

Orpen, C. (1994). The effects of organizational and individual career management on career success. International Journal of Manpower, 15(1), $27-37$.

Pyöriä, P., Ojala, S., Saari, T., \& Järvinen, K.-M. (2017). The millennial generation: A new breed of labour? sage Open, 7(1), 2158244017697158. Available at: https://doi.org/10.1177/2158244017697158.

Rasdi, R. M., Garavan, T. N., \& Ismail, M. (2011). Understanding proactive behaviours and career success: Evidence from an emerging economy. Organizations and Markets in Emerging Economies, 2(2), 53-71. Available at: https://doi.org/10.15388/omee.2011.2.2.14281.

Ringle, C. M., Wende, S., \& Will, A. (2005). Smart PLS version 2.o M3 Beta. Germany: University of Hamburg.

Seibert, S. E., Kraimer, M. L., \& Crant, J. M. (2001). What do proactive people do? A longitudinal model linking proactive personality and career success. Personnel Psychology, 54(4), 845-874. Available at: https://doi.org/10.1111/j.17446570.2001.tbo0234.x.

Sekaran, U., \& Bougie, R. (2010). Research methods for business: A skill building approach. London: Wiley.

Strauss, K., Griffin, M. A., \& Parker, S. K. (2012). Future work selves: How salient hoped-for identities motivate proactive career behaviors. Journal of Applied Psychology, 97(3), 580-598. Available at: https://doi.org/10.1037/a0026423.

Stumpf, S. A., Colarelli, S. M., \& Hartman, K. (1983). Development of the career exploration survey (CES). Journal of Vocational Behavior, 22(2), 191-226. Available at: https://doi.org/10.1016/0001-8791(83)90028-3.

Super, D. E. (1990). A life span, life-space approach to career development. In D. Brown, \& L. Brooks (Eds.), Career choice and development (2nd ed.). San Francisco: Jossey-Bass.

Tansley, D. P., Jome, L. M., Haase, R. F., \& Martens, M. P. (2007). The effects of message framing on college students' career decision making. Journal of Career Assessment, 15(3), 301-316. Available at: https://doi.org/10.1177/1069072707301204.

Tran, T. T. (2016). Journal of Teaching and Learning for Graduate Employability. Journal of teaching and learning for graduate employability, 7(1), 58-71.

Verma, P., Nankervis, A., Priyono, S., Salleh, N. M., Connell, J., \& Burgess, J. (2018). Graduate work-readiness challenges in the Asia-Pacific region and the role of HRM. Equality, Diversity and Inclusion: An International Journal, 37(2), 121 - 137.

Walsh, A., \& Kotzee, B. (2010). Reconciling 'graduateness' and work-based learning. Learning and Teaching in Higher Education(4-1), 36-50. Available at: https://doi.org/10.1108/heswbl-07-2017-0042.

Wolff, H.-G., \& Moser, K. (2009). Effects of networking on career success: A longitudinal study. Journal of Applied Psychology, 94(1), 196-206. Available at: https://doi.org/10.1037/a0013350.

Woo, C. H., \& Park, J. Y. (2017). Specialty satisfaction, positive psychological capital, and nursing professional values in nursing students: A cross-sectional survey. Nurse Education Today, 57, 24-28. Available at: https://doi.org/10.1016/j.nedt.2017.06.010. 